\title{
IMIGRACJA ZAROBKOWA OBYWATELI PAŃSTW BYŁEGO ZSSR SZANSĄ ROZWOJU POLSKICH PRZEDSIĘBIORSTW
}

\section{Streszczenie}

Cel - Celem artykułu jest udzielenie odpowiedzi na pytanie: dlaczego polskie przedsiębiorstwa zatrudniają cudzoziemców z obszaru byłego ZSRR oraz w jaki sposób wpływają oni na rozwój tych przedsiębiorstw.

Metodyka badania - w artykule zastosowano narzędzie badawcze jakim jest wywiad pogłębiony przeprowadzony z przedstawicielami polskich przedsiębiorstw zatrudniających cudzoziemców z obszaru byłego ZSRR. Dokonano również analizy danych statystycznych odnośnie migracji zarobkowej cudzoziemców w Polsce.

Wynik - Na podstawie analizy danych statystycznych można zaobserwować wzrastającą liczbę cudzoziemców ze Wschodu, a przede wszystkim z Białorusi i Ukrainy, którzy podejmują pracę zarobkową w Polsce. Głównym powodem tego zjawiska są zarobki, gdyż dobra praca w Polsce to nawet trzy razy większa płaca niż w kraju ojczystym. Pracownicy ze Wschodu stają się cenieni przez polskich pracodawców, gdyż posiadają oni doświadczenie w pracy, znajomość kultury polskiej, większość ma Kartę Polaka, co ułatwia ich zatrudnianie. Ponadto wielu z cudzoziemców chce się osiedlić na stałe w Polsce. Pracownicy ze Wschodu przyczyniają się też do rozwoju przedsiębiorstw, gdyż uzupełniają braki kadrowe, co pozwala na zawieranie nowych kontraktów biznesowych przez przedsiębiorstwa i zwiększenie ich zysku.

Oryginalność/wartość - Wykorzystanie wywiadów pogłębionych do ustanowienia faktycznych przyczyn migracji zarobkowych obywateli państw byłego ZSSR oraz tego, w jaki sposób ich praca wpływa na rozwój polskich przedsiębiorstw, co zostało ustalone na podstawie rozmów z przedsiębiorcami.

Słowa kluczowe: rozwój, przedsiębiorstwo, imigracja zarobkowa

\section{ECONOMIC MIGRATION OF CITIZENS OF THE FORMER SOVIET UNION AS AN OPPORTUNITY FOR THE DEVELOPMENT OF POLISH ENTERPRISES}

\section{Summary}

Goal - The aim of the article is to answer the question why Polish enterprises employ foreigners from the former USSR area and how they affect the development of these enterprises.

Research methodology - The article uses a research tool, which is an in-depth interview conducted with representatives of Polish enterprises, employing foreigners from the former USSR. The statistical data on labour migration of foreigners in Poland was also analyzed.

Score - Based on the analysis of statistical data, one can observe an increasing number of foreigners from the East, and above all, from Belarus and Ukraine, who take up paid 
employment in Poland. The main reason for this phenomenon is earnings, because good jobs in Poland offer up to three times higher wages than in their country. Employees from the East become valued by Polish employers, because they have work experience, knowledge of the Polish culture and most of them have a Polish Card, what makes their employment easier. In addition, many of the foreigners want to settle permanently in Poland. Employees from the East also contribute to the development of enterprises, because they supplement staff shortages, which, as a result, allows to conclude new business contracts by enterprises and increase their profit.

Originality /value - Using in-depth interviews to establish the actual causes of labor migration of former USSR citizens and how their work influences the development of Polish enterprises, which was established on the basis of talks with entrepreneurs.

Keywords: development, entrepreneurship, labor migration

DOI: 10.15290/wpewbmn4.2020.09

\section{Wprowadzenie}

Migracja jest jednym z głównych warunków niezawodnego funkcjonowania rynku pracy oraz rozwoju przedsiębiorstw. Od wielkości oraz kierunków migracji zarobkowej zależą zarówno popyt jak i podaż pracy w gospodarce narodowej w ujęciu ilościowym i jakościowym. Uwzględnienie migracji jest szczególnie ważne przy analizie procesów tworzenia wewnętrznego rynku pracy w okresie integracji Polski ze współczesną gospodarką światową. Ilościowy i jakościowy skład zasobów pracy w połączeniu z innymi czynnikami określa tempo rozwoju gospodarczego kraju poprzez rozwój krajowych przedsiębiorstw, poziom dobrobytu ludności, ogólny potencjał ekonomiczny systemu społeczno-gospodarczego jako całości. W warunkach transformacji polskiej gospodarki problemy ekonomiczne oraz sprzeczności związane ze zmianami w strukturach politycznych, społecznych i gospodarczych pociągają za sobą wzrost skali migracji zewnętrznej. W związku z powyższym wpływ międzynarodowej imigracji, a w szczególności tej o charakterze zarobkowym z państw byłego ZSSR do Polski, wymaga dogłębnej analizy pod kątem jej przyczyn oraz skutków, czyli w jaki sposób oddziaływuje ona na rozwój polskich przedsiębiorstw.

\section{Teoretyczne aspekty migracji zarobkowej}

Za początek ekonomicznej analizy migracji uznaje się dzieło A. Smitha, który zauważył zróżnicowanie wynagrodzeń (przewyższające zróżnicowanie cen dóbr) na terytorium Królestwa Wielkiej Brytanii, od Londynu - gdzie płace były najwyższe, po peryferia stolicy, a dalej po Edynburg i dalsze regiony Szkocji, gdzie płace kształtowały się na poziomie ponad dwukrotnie niższym niż w Londynie ${ }^{1}$. Ekonomista zaznacza, że migracja jest wynikiem przestrzennego zróżnicowania płac²

\footnotetext{
A. Piekutowska, Imigracja zarobkowa i jej wpływ na rynek pracy, CeDeWu, Warszawa 2019, s. 30.

2 O.B. Bodvarsson, N.B. Simpson, Ch. Sparber, Migration Theory, [w:] Handbook of the Economics of International Migration, vol. 1A, B.R. Chiswick, P.W. Miller (red.), Elsevier, North Holland 2015, s. 102.
} 
Pierwsze próby teoretycznych badań nad migracją międzynarodową zostały podjęte w 1885 roku przez niemieckiego demografa Ernesta Georga Ravensteina, w związku z którymi powstały powszechnie znane „prawa migracji”. Jego poglądy, podobnie jak poglądy innych przedstawicieli neoklasycznego podejścia do międzynarodowej migracji zarobkowej (na przykład amerykańskich ekonomistów Arnella Lewisa i Michaela Todaro), opierają się na kilku kluczowych zasadach. W szczególności zakłada się, że przepływy migracyjne wynikają z różnic w poziomie płac oraz warunków zatrudnienia pomiędzy państwami, jak również z kosztów procesu migracji. Według przedstawicieli ekonomii neoklasycznej przyczyny międzynarodowej migracji zarobkowej polegają na indywidualnych decyzjach ludzi, którzy pragną zwiększyć dochody osobiste ${ }^{3}$. Późniejsze podejścia ekonomii neoklasycznej do migracji zarobkowej opierają się nie tylko na analizie stanu rynków pracy jako głównej przyczynie migracji. Ekonomiści w swoich badaniach nad migracją brali pod uwagę stan systemu usług socjalnych w kraju przyjmującym. Współczesne teoretyczne poglądy na temat migracji zarobkowej nadal wynikają z neoklasycznej koncepcji korelacji czynników (determinantów) „pchania” i „ciągnięcia” populacji i pracy jako głównych sił napędowych tego procesu ${ }^{4}$. Tak więc nadwyżka zasobów pracy migruje z obszarów wiejskich do bardziej rozwiniętych miast, chociaż decyzje dotyczące migracji są często wynikiem osobistych pomysłów, a nie rzeczywistego stanu rzeczy.

Teoria dualistycznego rynku pracy Michaela Piora powiązała imigrację z zapotrzebowaniem na siłę roboczą $\mathrm{w}$ różnych sektorach gospodarki, co powoduje imigrację zarówno wysoko wykwalifikowanych specjalistów, jak i nisko wykwalifikowanej siły roboczej ${ }^{5}$. Immanuel Wallerstein rozważa migrację w kontekście globalizacji gospodarczej i rozwoju procesów integracyjnych. W badaniach dotyczących kulturowych i etnicznych elementów migracji podkreśla się rolę diaspor narodowych w angażowaniu nowych imigrantów w obszary działalności różnych etnicznych migrantów, co staje się zauważalnym czynnikiem w rozwoju małych przedsiębiorstw w krajach otrzymujących pomoc ${ }^{6}$. Można powiedzieć, że pod koniec XX i na początku XXI wieku międzynarodowa migracja zarobkowa jest postrzegana jako proces wielowymiarowy, obejmujący indywidualnych obywateli, sieci społeczne, systemy komunikacyjne oraz rozległe międzynarodowe struktury i instytucje gospodarcze, w tym rządy poszczególnych krajów.

\footnotetext{
3 E.G. Ravenstein, The Laws of Migration, Second Paper, ,Journal of the Royal Statistical Society” 1889, vol. 52, no. 2, s. 286.

4 M. Nowak, Polska migracja: motywy motywy mobilności, jej dynamika i propozycja socjologicznej rekonceptualizacji, „Ruch prawniczy, ekonomiczny i socjologiczny” 2014, z. 3, s. 281-298.

5 M. Piore, Birds of passage: Migrant labour and industrial societies. Cambridge University Press, Cambridge 1979.

${ }_{6}$ I.Wallerstein, The Modern World System I: Capitalist Agriculture and the Origins of the European World Economy in the Sixteenth Century, University of California Press 2011, s. 102.
} 


\section{Przyczyny imigracji zarobkowych}

Migracja ludności jest zjawiskiem naturalnym, które istniało od zawsze, ale obecnie staje się coraz bardziej powszechne. Przyczyny migracji mogą być bardzo różne: nie tylko dążenie do lepszego życia, ale czasami jedyny sposób na przetrwanie. Do głównych przyczyn imigracji zarobkowych należą czynniki gospodarcze, kulturowe, środowiskowe, polityczne, narodowe, religijne, rasowe, psychologiczne, humanitarne oraz prawne. W tym punkcie artykułu zostaną przedstawione najczęściej wymieniane w teorii przyczyny imigracji zarobkowych oraz ujawnione przez imigrantów faktyczne powody podjęcia decyzji o pracy w Polsce, które zostały ustalone podczas wywiadu pogłębionego. Podczas badań przyczyn migracji zarobkowych obywateli byłego ZSSR autor nie bierze pod uwagę migracji przymusowych lub mających na celu łączenie rodzin, jak również osób ubiegających się o azyl7. W przeprowadzonych badaniach uczestniczyły osoby, które dobrowolnie podjęly decyzję o opuszczeniu swojego kraju i przyjechaniu do Polski w celach zarobkowych.

Głównym powodem migracji zarobkowych jest znacząca rozbieżność w wynagrodzeniach w różnych krajach. Jako przykład można podać zamykanie przedsiębiorstw, dzięki którym miasto lub regiony się rozwijały. W takich przypadkach mieszkańcy tracą pracę i rozpoczyna się masowy odpływ ludności w poszukiwaniu nowych możliwości zarobkowych.

Analiza porównawcza liczby zezwoleń na pracę rozpoczyna się od 2008 roku, czyli w okresie, w którym jest zaobserwowany wzrost liczby imigrantów zarobkowych z krajów byłego ZSSR (tabela 1).

Tabela 1 .

Dynamika zmian liczby zezwoleń na pracę wydawanych w latach 2008-2018 według kraju pochodzenia pracowników

\begin{tabular}{l|c|c|c|c|c}
\hline Lata & Ukraina & Białoruś & Mołdawia & Armenia & Rosja \\
\hline 2008 & 5400 & 1325 & 1218 & 441 & 429 \\
\hline 2009 & 9504 & 1669 & 601 & 619 & 540 \\
\hline 2010 & 12894 & 1937 & 675 & 448 & 491 \\
\hline 2011 & 18669 & 1725 & 1017 & 457 & 549 \\
\hline 2012 & 20295 & 1949 & 616 & 475 & 719 \\
\hline 2013 & 21252 & 2061 & 726 & 503 & 864 \\
\hline 2014 & 26315 & 1834 & 1027 & 363 & 654 \\
\hline 2015 & 57384 & 2203 & 1586 & 167 & 595 \\
\hline 2016 & 116522 & 5218 & 2861 & 143 & 1129 \\
\hline 2017 & 216048 & 11813 & 4408 & 219 & 1474 \\
\hline
\end{tabular}

Źródło: opracowanie własne na podstawie danych MRPiPS.

7 E.S. Lee, A Theory of Migration, „Demography”1966, vol. 3, no. 1, s. 51. 
Do Polski w celach zarobkowych z krajów byłego ZSSR przyjeżdżają najczęściej obywatele Ukrainy, Białorusi, Mołdawii, Armenii oraz Rosji. Warto zwrócić uwagę na dwukrotny wzrost imigrantów zarobkowych z Ukrainy w 2017 roku, który był spowodowany zniesieniem obowiązku posiadania wiz. Decyzje o opuszczeniu kraju są podyktowane różnorakimi przesłankami. Motywy mogą mieć charakter następujący ${ }^{8}$ :

- polityczny. Ludzie opuszczają ojczyznę z powodu prześladowań za swoje przekonania polityczne, poglądy na życie, które są sprzeczne z oficjalną polityką elity rządzącej;

- ekologiczny. Katastrofy spowodowane przez człowieka lub niekorzystna ekologia często prowadzą do braku warunków do życia i pracy, przez co ludzie muszą szukać nowego miejsca w innym kraju;

- ekonomiczny. Czynniki takie jak bezrobocie, wysokie podatki oraz inflacja, które prowadzą do ubóstwa, niezdolności do utrzymania siebie i swojej rodziny. Ludzie zaczynają szukać możliwości zarobku w innych krajach, o bardziej lojalnej polityce społecznej;

- wojskowe. Długie wojny, starcia zbrojne prowadzą do tego, że prawie cała ludność $\mathrm{w}$ wieku produkcyjnym staje się stroną konfliktu. W rezultacie gospodarka cierpi, a szanse na zarobki znikają. Ta sytuacja prowadzi do przymusowego poszukiwania możliwości zarobkowych w innym kraju.

Jednym z głównych problemów wschodniego rynku pracy jest „odpływ inteligencji”. Wysoko wykwalifikowani specjaliści opuszczają kraj w poszukiwaniu interesującej i dobrze płatnej pracy. Wśród przebadanych $70 \%$ osób uważa, że przyjazd do Polski jest opłacalny i korzystny, w związku z czym planują kontynuować swoją pracę dalej ${ }^{9}$. Prawie trzech na pięciu respondentów przyznało, że nie widzi swojej przyszłości w swoim kraju, natomiast $95 \%$ osób nie jest zadowolona z wielkości płac i poziomu rozwoju gospodarczego. Ponad połowa uważa za niemożliwe pozostanie w kraju, w którym prawa nie są przestrzegane, a korupcja kwitnie. Ponadto trzy z pięciu osób są zaniepokojone trudną sytuacją polityczną w państwie. Jedna trzecia imigrantów zarobkowych poprzez wyjazd poszukuje dobrej medycyny, edukacji oraz ubezpieczenia społecznego. Nieco więcej niż połowa respondentów jest przekonana, że w Polsce można zarabiać znacznie więcej, wykonując nawet mniej prestiżową pracę, niż w kraju ojczystym. Badane osoby podczas wywiadów rzadko wspominały o poczuciu bezpieczeństwa, możliwości profesjonalnej samorealizacji oraz uproszczonej procedurze rejestracji własnej działalności gospodarczej. Główne przyczyny imigracji zarobkowej do Polski obywateli państw byłego ZSSR przedstawia wykres 1.

\footnotetext{
8 Serwis Emigranto, www.emigranto.ru [dostęp: 03.05.2019].

9 Badania do niniejszego artykułu zostały przeprowadzone w okresie styczeń - marzec $2019 \mathrm{r}$. W wywiadach wzięło udział 115 osób, w wieku 25-50 lat, którzy posiadają obywatelstwo kraju byłego ZSSR oraz mają aktualne pozwolenie na pracę na terytorium RP. W pierwszym etapie do wybranych osób zostały wysłane ankiety weryfikujące przynależność do badanej grupy, następnie zostały przeprowadzone z migrantami wywiady indywidualne.
} 
Wykres 1 .

Główne przyczyny migracji zarobkowej do Polski obywateli państw byłego ZSSR

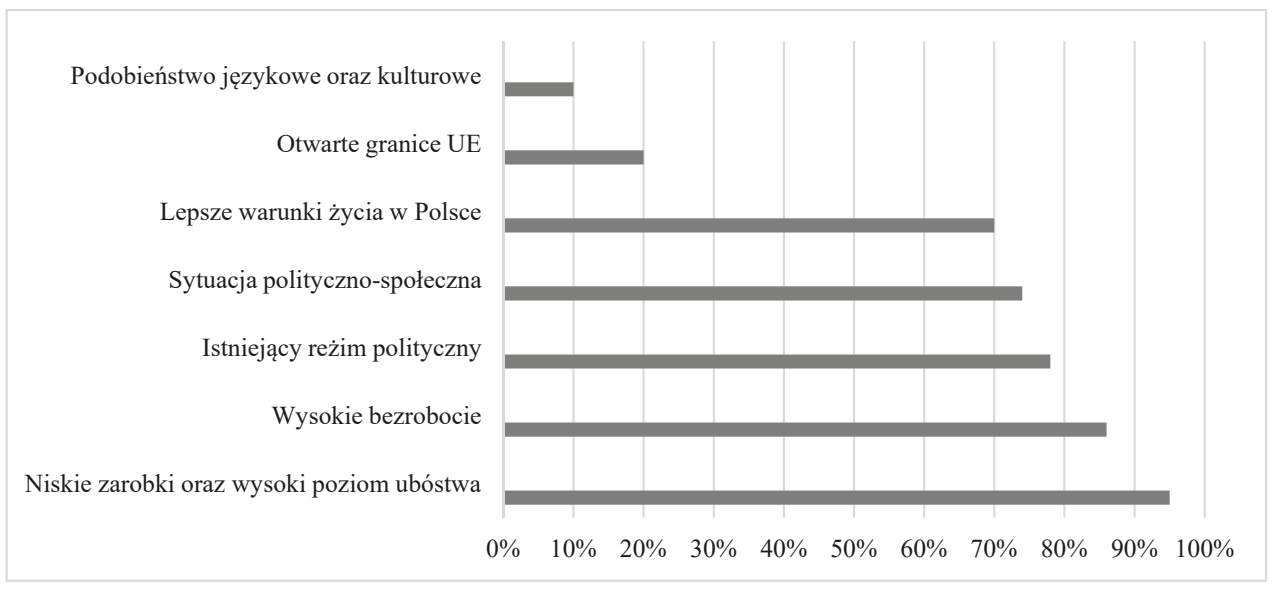

Źródło: opracowanie własne na podstawie przeprowadzonych badań.

Przyczyn międzynarodowej migracji zarobkowej jest bardzo dużo i trudno wyznaczyć jej główne powody. Z pełnym przekonaniem można jedynie powiedzieć, że każda osoba, kierując się instynktem samozachowawczym, stara się w jakikolwiek sposób zapewnić sobie jedzenie, ubranie oraz schronienie.W przypadku braku możliwości znalezienia rozwiązania tego problemu, osobom tym nie pozostaje nic innego jak przeprowadzić się do innego państwa, w którym zapewnia się bardziej korzystne warunki życia.

\section{Imigracja zarobkowa szansą rozwoju polskich przedsiębiorstw}

W roku 2017 w Polsce zarejestrowano o 40\% więcej oświadczeń dotyczących zamiaru powierzenia wykonywania pracy cudzoziemcom w stosunku do 2016 roku, wynosząc około 1,8 mln oświadczeń. Według badania Plany Pracodawców, przygotowanego przez Instytut Badawczy Randstad, wśród wszystkich cudzoziemców, którzy przyjechali do pracy do Polski, zdecydowaną większość stanowili Ukraińcy (85\%), natomiast pozostałe $15 \%$ - Białorusini $(13 \%)$ oraz obywatele pozostałych krajów (2\%). Z raportu Ministerstwa Rodziny Pracy i Polityki Społecznej wynika, że 82 tys. pracodawców zarejestrowało chęć powierzenia pracy cudzoziemcowi ${ }^{10}$. Zamiar powierzenia pracy wynika nie tylko z kosztów zatrudnienia imigrantów, ale również ze specyficznych kompetencji i umiejętności, które posiada imigrant zarobkowy. Wykres 2 przedstawia strukturę oświadczeń zarejestrowanych w 2017 roku.

${ }^{10}$ Serwis MRPiPS, https://www.gov.pl/web/rodzina [dostęp: 03.05.2019]. 
Wykres 2 .

Struktura oświadczeń zarejestrowanych w 2017 r. w \%

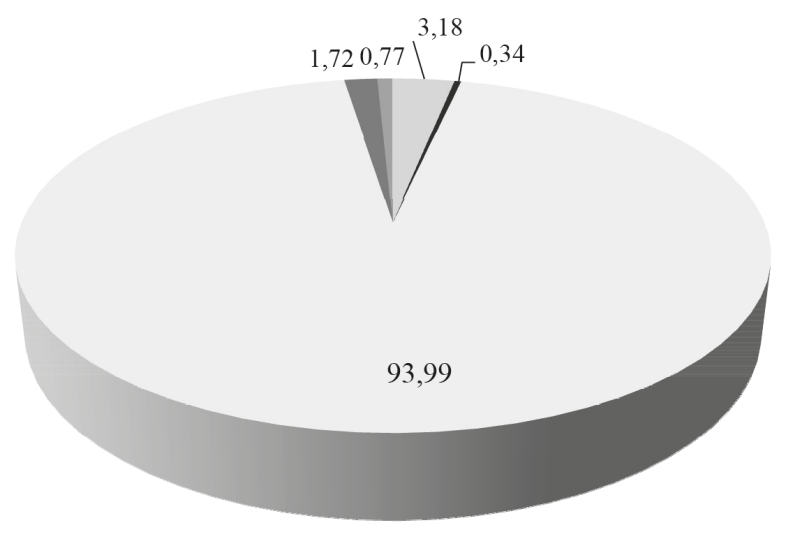

Białoruś $\quad$ Rosja Ukraina $\square$ Mołdawia $\square$ inne

Źródło: opracowanie własne na podstawie danych MRPiPS.

W celu dokładnego zbadania tematu, w jaki sposób imigranci wpływają na rozwój polskich przedsiębiorstw, przeprowadzono wywiady z pracodawcami, którzy zatrudniają obywateli państw byłego ZSSR. W badaniu wzięło udział 78 pracodawców ${ }^{11}$.

Celem pierwszej części badania było ustalenie wizerunku pracowników ze Wschodu, jak również przedstawienie opinii polskich pracodawców oferujących im miejsce zatrudnienia. Na podstawie otrzymanych wyników sformułowano następujące wnioski:

- $\quad$ wysoko wykwalifikowani obcokrajowcy przynoszą do Polski umiejętności, których nie zapewnia polski system edukacji. Poprzez zatrudnianie imigrantów pracodawcy zyskują pracowników różniących się pod względem wykształcenia, umiejętności i doświadczenia. Polskie przedsiębiorstwa chętnie przyjmują osoby ze Wschodu, ponieważ znajomość kultury obcej oraz doświadczenie zawodowe zdobyte poza granicami kraju moga zwiększyć szansę na wdrożenie nowej oferty produkcyjnej i rozwój firmy;

- $\quad$ pracownicy ci wnoszą do organizacji inne spojrzenie i rożne punkty widzenia, ponieważ posiadają specyficzne doświadczenie, które zdobyli w innych warunkach społeczno-kulturowych. Fakt ten wskazuje na to, że mogą oni nie tylko podzielić się uzyskaną wiedzą, ale również zaproponować inne praktyczne rozwiązania istniejącego problemu;

\footnotetext{
${ }^{11}$ Badania do niniejszego artykułu zostały przeprowadzone w okresie styczeń - kwiecień 2019 r. Wywiady zostały przeprowadzone z pracodawcami, którzy zatrudniają obywateli państw byłego ZSSR.
} 
- przy zatrudnianiu pracowników obowiązują uproszczone procedury zatrudnienia. „Zgodnie z $\$ 1$ pkt 20 rozporządzenia Ministra Pracy i Polityki Społecznej z dnia 21 kwietnia 2015 roku powierzenie wykonywania pracy cudzoziemcowi pochodzącemu z Armenii, Białorusi, Gruzji, Mołdawii, Rosji, Ukrainy na terytorium Rzeczpospolitej Polskiej jest dopuszczalne bez konieczności uzyskania zezwolenia na pracę, czyli na podstawie tzw. uproszczonej procedury zatrudniania" ${ }^{12}$. Należy wziąć pod uwagę pracowników, którzy zgodnie z ustawą z dnia 7 września 2007 roku o Karcie Polaka są zwolnione z obowiązku posiadania zezwolenia na pracę i mogą pracować na takich zasadach jak obywatele polscy;

- zagranicznych pracowników cechuje silna motywacja do pracy, ponieważ płace w kraju ojczystym i w Polsce znacząco różnią się od siebie i w związku z tym posiadają większą chęć do wykonywania zawodu. Cudzoziemcy cenią swoje szanse zarobkowe i poważnie podchodzą do powierzonych im zadań;

- pracowników ze Wschodu uważa się za tańszą siłę roboczą, przez co są rozchwytywani na rynku pracy nie tylko ze względu na posiadaną specjalistyczną wiedzę, ale i dlatego, że nie mają wygórowanych oczekiwań względem płac. Polscy pracodawcy oferują stawki ponad dwukrotnie wyższe niż na Wschodzie, w związku z czym pracownicy godzą się na współpracę, a firmy obniżają koszty związane z zatrudnieniem.

W drugiej części badania ustalono motywy decydujące o zatrudnieniu imigrantów ze Wschodu, które były spójne z wnioskami prezentowanymi w pierwszej części. Wśród przyczyn zatrudniania obywateli państw z obszaru byłego ZSSR respondenci najczęściej wskazywali:

- niższe koszty zatrudnienia - powszechnie znany jest fakt, że pracownicy ze Wschodu akceptują niższe stawki płacowe niż te, jakie akceptują polscy specjaliści. Z wyników badań Narodowego Banku Polskiego wynika, że średnia miesięczna płaca imigranta wynosi około $2000 \mathrm{z}^{13}$, natomiast w kraju ojczystym ich dochody wynoszą w granicach 500-850 zł. W związku z powyższym imigranci zarobkowi nie stawiają zbyt wysokich oczekiwań zarobkowych, gdyż na początku mogą liczyć na ponad dwukrotnie większe wynagrodzenie niż w kraju macierzystym;

- posiadanie specyficznych umiejętności oraz wiedzy - należy przez to rozumieć znajomość języków obcych (zatrudnianie do obsługi klientów zagranicznych) oraz wiedza na temat rynków, z którymi firma posiada relacje lub planuje je nawiązać;

\footnotetext{
${ }^{12}$ Rozporządzenie Ministra Pracy i Polityki Społecznej z dnia 21 kwietnia 2015 r. w sprawie przypadków, w których powierzenie wykonywania pracy cudzoziemcowi nie terytorium Rzeczpospolitej Polskiej jest dopuszczalne bez konieczności uzyskania zezwolenia na pracę. Dz.U. z 2015 poz. 588 .

${ }^{13}$ NBP, https://www.nbp.pl [dostęp: 10.05.2019].
} 
- $\quad$ podobieństwo językowe oraz kulturowe - pracodawcy preferują zatrudnianie pracowników ze Wschodu, gdyż różnice kulturowo-językowe nie są znaczące, a firmy nie muszą ponosić dodatkowych kosztów związanych z ich przeszkoleniem;

- uzupełnienie braków kadrowych - w sytuacjach, gdy na rynku lokalnym brakuje odpowiednio wykwalifikowanych i przeszkolonych kandydatów, przedsiębiorcy w takich przypadkach decydują się na przyjęcie imigrantów ze Wschodu, ponieważ w taki sposób są oni w stanie uzupełniać na bieżąco niedobory kadrowe;

- możliwość powierzenia zadań w dni wolne i święta - imigranci z państw byłego ZSRR są powszechnie uważani za bardzo solidnych i wydajnych pracowników ze względu na fakt, że są oni w stanie wykonywać swoją pracę nie tylko w podstawowym zakresie, ale również angażować się $\mathrm{w}$ dodatkowe projekty w ramach nadgodzin oraz w dni wolne (taki tryb pracy jest postrzegany przez nich jako szansa, a nie zło konieczne).

Odpowiedzi na pytania polskich pracodawców pozwalają na stwierdzenie, że zatrudnienie imigrantów uzupełnia niedobór powstały na polskim rynku pracy i ma charakter komplementarny. Wśród ankietowanych przedsiębiorców $90 \%$ zaznaczyło, że dzięki obcokrajowcom udało im się utrzymać stabilność produkcji i zatrudnienia. $W$ trakcie ustalania przyczyn zatrudniania imigrantów respondenci wskazywali również, w jaki sposób pracownicy ze Wschodu wpływają na rozwój przedsiębiorstw.

W jaki sposób wpływają na rozwój przedsiębiorstw? Z przeprowadzonych wywiadów wynikają główne przesłanki zatrudniania imigrantów:

- uzupełnienie braków kadrowych. Obniżenie wieku emerytalnego, niż demograficzny oraz wysoki poziom emigracji są największymi problemami utrudniającymi prowadzenie działalności gospodarczej w Polsce. W opinii przedsiębiorców tylko pracownicy zza wschodniej granicy mogą uzupełnić niedobory kadrowe i chwilowo rozwiązać istniejący problem;

- optymalizacja kosztów. Jako jeden z głównie wymienianych powodów zatrudniania cudzoziemców ze Wschodu wskazywana jest możliwość zaoferowania niższego wynagrodzenia, co znacząco obniża koszty działalności przedsiębiorstwa. Imigranci, posiadają również wiedzę i umiejętności zdobyte w kraju ojczystym, w związku z czym pracodawca nie musi inwestować w przeszkolenie nowego pracownika;

- zapewnienie ciągłości produkcji. Jak już wcześniej zostało zaznaczone, dzięki napływowi imigrantów do Polski, przedsiębiorcy mogą uzupełnić braki kadrowe i zapewnić ciągłość produkcji poprzez m.in. możliwość powierzenia pracy w dni wolne i święta oraz tzw. zmiany nocne. Pracodawcy nawiązywali także do uproszczonej procedury zatrudniania, co pozwala rozpocząć współpracę w dowolnym momencie, nie czekając na uzyskanie pozwolenia. 
Polskie przedsiębiorstwa coraz chętniej zatrudniają imigrantów, co potwierdza pozytywna opinia pracodawców oraz ich zauważalny wpływ na rozwój firm. Podczas wywiadu wskazano na jeszcze jeden pozytywny czynnik przyczyniający się do poprawy finansowej przedsiębiorstw - w związku z dużym napływem imigrantów firmy wprowadzają dodatkowe usługi i produkty dla obcokrajowców, dzięki czemu zwiększają swoje portfolio oraz zyski.

\section{Podsumowanie}

Obywatele państw byłego Związku Radzieckiego nadal starają się wyemigrować do Polski, pomimo wszelkich podejmowanych działań lokalnych władz, które mają na celu poprawę sytuacji finansowej ludności poprzez np. zwiększenie płac minimalnych. Mimo to wynagrodzenia za podobną pracę w Polsce są znacznie wyższe niż w ojczyźnie i to powoduje, że duża część młodych ludzi w wieku produkcyjnym wyjeżdża za granicę. Polskich pracodawców interesują najbardziej osoby gotowe do pracy w tych obszarach gospodarki, w których brakuje lokalnych specjalistów lub gdzie miejscowi nie chcą pracować ze względu na niskie wynagrodzenie. Na podstawie oficjalnych danych statystycznych i przeprowadzonych badań można zaobserwować, że imigranci zarobkowi to osoby w wieku produkcyjnym, dobrze wykształceni oraz posiadający chęć do pracy. Poprzez zatrudnienie obcokrajowców polskie przedsiębiorstwa zyskują niskim kosztem cenny potencjał zagranicznych pracowników, co przekłada się nie tylko na rozwój, ale i na konkurencyjność firmy na rynku lokalnym i międzynarodowym.

\section{Literatura}

Bodvarsson O.B, Simpson N.B., Sparber Ch., Migration Theory, [w:] Handbook of the Economics of International Migration, vol. 1A, Chiswick B.R., Miller P.W. (red.), Elsevier, North Holland 2015.

Lee E.S., A Theory of Migration, „Demography” 1966, vol. 3, no. 1.

Nowak M., Polska migracja: motywy mobilności, jej dynamika i propozycja socjologicznej rekonceptualizacji, „Ruch prawniczy, ekonomiczny i socjologiczny” 2014, z. 3.

Piekutowska A., Imigracja zarobkowa i jej wptyw na rynek pracy, CeDeWu, Warszawa 2019.

Piore M., Birds of passage: Migrant labour and industrial societies, Cambridge University Press, Cambridge 1979.

Ravenstein E.G., The Laws of Migration, Second Paper, „Journal of the Royal Statistical Society" 1889 , vol. 52 , no. 2.

Rozporządzenie Ministra Pracy i Polityki Społecznej z dnia 21 kwietnia 2015 r. w sprawie przypadków, w których powierzenie wykonywania pracy cudzoziemcowi nie terytorium Rzeczpospolitej Polskiej jest dopuszczalne bez konieczności uzyskania zezwolenia na pracę. Dz.U. z 2015, poz. 588.

Wallerstein I., The Modern World System I: Capitalist Agriculture and the Origins of the European World Economy in the Sixteenth Century, University of California Press 2011.

Wrona M., Imigracja a gospodarka. Doświadczenia Australii, CeDeWu, Warszawa 2016. 


\section{Źródła elektroniczne}

Serwis Emigranto, www.emigranto.ru [dostęp: 10.05.2019].

Narodowy Bank Polski, https://www.nbp.pl [dostęp: 10.05.2019].

Ministerstwo Rodziny, Pracy i Polityki Społecznej, https://www.gov.pl/web/rodzina [dostęp: 03.05.2019]. 